\title{
Oral Alterations in a COVID-19 Patient: Case Report and Update of Main Findings
}

\author{
Alteraciones Orales en un Paciente con COVID-19: \\ Reporte de un Caso y Actualización de los Principales Hallazgos
}

\begin{abstract}
Amanda Claudino Gomes'; Diogo da Silva Ferreira'; Michelly de Melo Silva'; Caio César da Silva Barros ${ }^{2}$; Nicássio Silva Menezes ${ }^{3} \&$ Hellen Bandeira de Pontes Santos $^{4}$
\end{abstract}

GOMES, A. C.; FERREIRA, D. S.; SILVA, M. M.; BARROS, C. C. S.; MENEZES, N. S. \& SANTOS, H. B. P. Oral alterations in a COVID-19 patient: case report and update of main findings. Int. J. Odontostomat., 15(2):315-319, 2021.

ABSTRACT: COVID-19 was characterized as a pandemic due to the worldwide dissemination and the severity with which the disease attacks the human organism. Some oral lesions have been observed in COVID-19 patients. However, there is still no concrete evidence of the real influence of SARS-CoV-2 on the human body, especially in the oral region. In this context, the present report discusses a case of a COVID-19 patient with oral alterations. The male patient presented ulcerative lesions of painful symptomatology and petechiae in the oral mucosa. This study also performed a literature review of the main oral alterations reported in the literature. Although more studies with a larger number of cases should be performed, the present clinical case may have manifested signs of this pathology in the oral cavity since the epithelial cells of the oral mucosa have ACE2 receptors.

KEY WORDS: coronavirus, oral manifestations, oral health.

\section{INTRODUCTION}

Changing the global life scenario, the new coronavirus originated in East Asia spread rapidly around the world. On February 11th, the World Health Organization (WHO) termed it as COVID-19, caused by the severe acute respiratory syndrome coronavirus 2 (SARS-CoV-2). A month after, COVID19 was characterized as a pandemic due to the worldwide spread and the severity with which the disease attacks the human body (Hamed, 2020).

Coronaviruses, belonging to the Coronaviridae family, are classified as simple, highly diverse RNA viruses, which mutate easily (Weiss \& Navas-Martin, 2005). In humans, COVID-19 infections mainly affect the respiratory and gastrointestinal tracts, with manifestations ranging from common colds to acute pneumonia (Hamed; Guan et al., 2020). Recent literature reports some of the complications that SARS-CoV-2 may manifest when coming into contact with the human organism. The WHO highlights that cough, fever, tiredness, runny nose, sore throat, and difficulty breathing are still the most common symptoms of current infection (Hamed; Guan et al.).

In this new scenario, complications of this virus to the human being have been studied vehemently by several scientific groups, which dedicate themselves to research on the symptoms, immunization, and medications that help in reducing the effects of this virus on the organism. In some studies, oral alterations have been reported in patients with COVID-19 (Amorim Dos Santos et al., 2020; Carreras-Presas et al., 2020; Ciccarese et al., 2020; Lechien et al., 2020; Jimenez-Cauhe et al., 2020;

\footnotetext{
${ }^{1}$ Undergraduate student, Department of Dentistry, Nova Esperança School (FACENE), João Pessoa, PB, Brazil.

2 Oral Pathology and Medicine, Postgraduate Program in Dental Sciences, Federal University of Rio Grande do Norte, Natal, RN, Brazil.

${ }^{3}$ Physician, Nova Esperança Medical School (FAMENE), João Pessoa, PB, Brazil.

${ }^{4}$ Professor, Postgraduate Program in Health Family, Nova Esperança School (FACENE), João Pessoa, PB, Brazil.
} 
Kahraman \& Çaskurlu, 2020; Soares et al., 2020). In this context, this study reported a COVID-19 patient who presented oral alterations and assessed his clinical characteristics in comparison to cases in the literature.

\section{CASE REPORT}

A 22-year-old man, with a history of chronic asthma and recent contact with COVID-19 patients, presented with remarkable respiratory symptoms, severe headache, fever, odynophagia, cough, and runny nose. Associated with this condition, there were hyposmia and hypogeusia, as well as lack of appetite. Furthermore, there were no cutaneous changes in the patient. In the medical history, the patient reported allergic rhinitis and drug hypersensitivities, such as acetylsalicylic acid, non-steroidal anti-inflammatory, dipyrone, and penicillin. It was performed the SARSCOV-2 test by the method of immunochromatography with a whole blood sample, and a reagent sample for positive $\lg M$ and $\lg G$ was found, thus confirming the patient's exposure to the virus.
The patient reported that on the 2 nd day after the onset of symptoms, he felt discomfort in the lower gum and the inner surface of the lower lip. On intraoral physical examination, it was observed two shallow ulcerative lesions with painful symptoms and strong burning (Fig. 1A) and the presence of petechiae, which were not causing pain or discomfort, in the anterior region of the inner mucosa of the lower lip (Fig. 1B). The patient stated that there was no previous trauma in the area.

The patient reported that on the 3rd day after the onset of symptoms he used oral azithromycin $(500 \mathrm{mg})$ once a day for seven days, oral dexchlorpheniramine (2 mg) once a day for ten days, oral ivermectin (200 $\mathrm{mcg} / \mathrm{kg}$ ) in a single dose, and budesonide nasal spray once a day for five days. On the 9th day after the first symptoms, the patient reported a gradual return of taste and, without the use of any topical medication, presented a decrease in the number of petechiae as well as involution of ulcerative lesions (Fig. 2A). On the 11th and 15th day after the appearance of the first symptoms, it was possible to verify a smaller amount of petechiae and the complete healing, respectively, in the mucosa of the lower gum and the lower lip (Figs. 2B and $\mathrm{C})$.
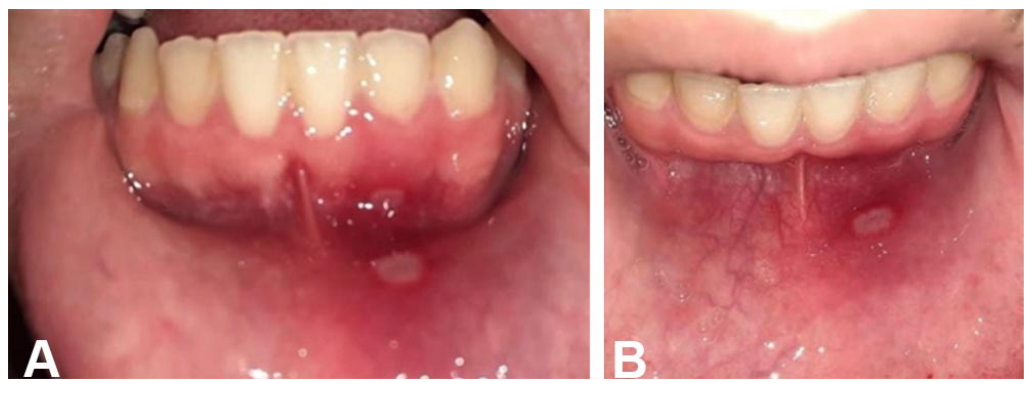

Fig. 1. (A) Two shallow ulcerative lesions located in the gum region and in the internal mucosa of the lower lip. (B) Ulcerative lesions located in the internal mucosa of the lower lip and ulcerative lesion located in the inner surface of the lower lip and petechiae in the anterior region of the lower lip mucosa.

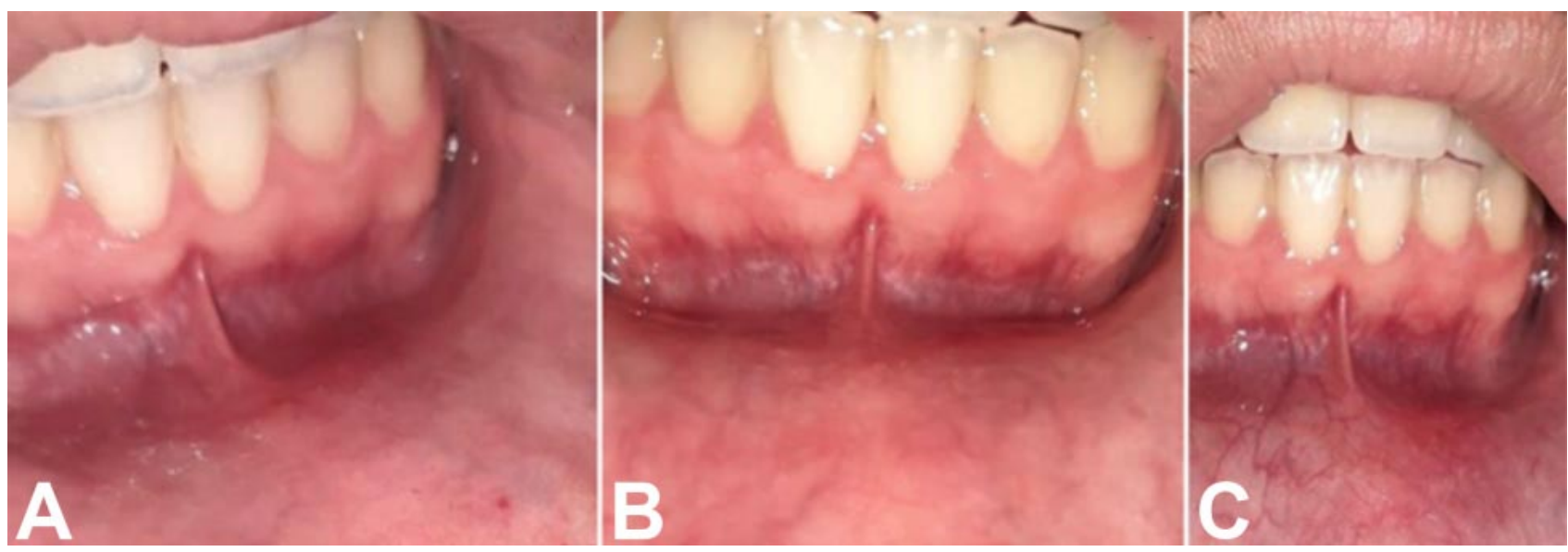

Fig. 2. Involution of ulcerative lesions and petechiae in the lower gum and the inner mucosa of the lower lip on the 9th (A) and 11 th (B) day. (C) Complete healing of the lower gum and the inner surface of the lower lip after 15 days after the onset of symptoms. 


\section{DISCUSSION}

Current research shows that SARS-CoV-2 enters the host cell by targeting the angiotensinconverting enzyme 2 (ACE2), the same receptor from SARS-CoV. Cells that have receptors for the ACE2 enzyme have the potential to become hosts for the virus, causing inflammation in the associated organs and tissues (Zhou et al., 2020; Zou et al., 2020). According to Xu et al. (2020), the oral mucosa may be a high-risk location for the potential development of COVID-19 infection. Although some clinical findings have suggested an association between oral alterations and SARS-CoV-2 infection, the data should be analyzed with caution due to the lack of information. In this way, it was analyzed six articles that have reported oral alterations, such as ulcers and petechiae in patients with COVID-19 (Amorim Dos Santos et al.; Carreras-Presas et al.; Ciccarese et al.; Jimenez-Cauhe et al.; Kahraman \& Çaskurlu; Soares et al.).

A European study with 417 patients with mild to moderate COVID-19 symptoms showed that the most prevalent general symptoms consisted of cough, myalgia, and loss of appetite. Of these, $85.6 \%$ and $88.8 \%$ of patients had olfactory dysfunction related to the infection and reported taste disorders with impairment of the four taste modalities, respectively, which appeared before the other symptoms (Lechien et al.). As shown in the study by Lechien et al., the patient presented here also had olfactory dysfunction and impairedtaste as well as general symptoms such as cough, myalgia, and loss of appetite.

Ciccarese et al. reported a case of a 19-yearold female patient with COVID-19, who presented erythematous macules, papules, and petechiae on the lower extremities on physical examination. It also was observed erosions, ulcers, and blood scabs on the inner surface of the lips, as well as petechiae on the palate and gums. For this patient, the initial antibiotic therapy was discontinued, and intravenous immunoglobulins $(400 \quad \mathrm{mg} / \mathrm{kg})$ and methylprednisolone $(1 \mathrm{mg} / \mathrm{kg}$ ) were administered for 5 days. These oral alterations are similar to those presented in the present clinical case, regarding the existence of petechiae and ulcerations in the oral mucosa region. It has been reported that patients with COVID-19 may develop thrombocytopenia and exhibit high D-dimer, which can be explained by the excessive activation of the coagulation cascade and platelets since viral infections can promote systemic inflammatory responses and cause an imbalance between procoagulant and anticoagulant homeostatic mechanisms (Giannis et al., 2020). Therefore, we suggest the possibility that petechiae located on the lower lip may be caused by changes in the coagulation cascade.

Similar to the present case, Jimenez-Cauhe et al. observed the presence of macules on the hard palate and petechiae in the oral cavity in three of the four reported cases. These three patients were treated with systemic corticosteroids and exhibited progressive resolution of the lesions within 2 to 3 days, while in our case, the patient showed clinical improvement of oral lesions over 2 to 3 weeks. Additionally, Kahraman \& Çaskurlu also reported the presence of a largely erythematous surface in the oropharynx and oral petechiae and numerous prominent pustular enanthem, ranging from 1-3 mm in diameter, in the palate of a 51-year-old male patient with COVID-19. Besides, this patient also stated anosmia and sore throat and showed regression of oral lesions after a few days of antibiotic therapy. These clinical findings reported in the literature suggest a possible association between these oral alterations and infection by the SARS-CoV-2 virus. However, there are still doubts as to whether these lesions are caused due to coronavirus infection or whether they represent secondary manifestations resulting from the systemic condition of these patients or pharmacological therapy performed.

Some authors have reported the occurrence of oral alterations associated with COVID-19, such as ulcers, blisters on the mucosa, and scaly gingivitis. Carreras-Presas et al. described oral lesions in one confirmed and two suspected COVID-19 patients. The confirmed patient had blisters on the internal mucosa of the lip, scaly gingivitis, and generalized skin rash, while the other two cases had painful palatal ulcers similar to herpetic lesions. Similarly, in the case reported by Amorim Dos Santos et al., it was observed as oral changes the presence of persistent white plaque and several ulcers on the dorsum of the tongue resembling the late stage of recurrent herpetic oral lesions.

Some authors have discussed the possibility of the relationship between these oral alterations and 
SARS-CoV-2 infection (Abu-Hammad et al., 2020; AlKhatib, 2020; Amorim Dos Santos et al.; Petrescu et al., 2020; Ponce \& Tjioe, 2020; Rocha et al., 2020). Abu-Hammad et al. emphasize the possibility of these oral changes being associated with other infections of viral or fungal etiology. Besides, these authors point out that many drugs have adverse effects, as impairment of the immune system, which increases the susceptibility of opportunistic infections to affect the oral mucosa. Also, the emotional stress associated with periods of social-life restrictions may promote changes in the health condition.

In the case reported by Soares et al., the patient exhibited an ulcerated lesion on the buccal mucosa and multiple reddish macules on the hard palate, tongue, and lips. Analysis through immunohistochemistry and in-situ hybridization revealed negativity for herpes simplex virus 1 and 2 , cytomegalovirus, treponema pallidum, and EpsteinBarr virus. It also was reported that the patient had a history of diabetes and hypertension and, when admitted to the hospital, presented petechiae and vesiculobullous lesions of unknown etiology on the skin, which was treated with dexamethasone and dipyrone for one week. In this way, we believe that the presence of ulcers in different locations of the oral cavity may be a relevant condition, but we also highlight that caution is advised when associating the appearance of ulcers or other oral alterations with COVID-19.

\section{CONCLUSION}

Due to the COVID-19 be a recent disease and the lack of information related to it, there is still no concrete evidence of the real influence of SARS-CoV-2 on the human body, especially in the oral region. However, given the mentioned clinical findings, the possibility of the patient of the present clinical case having manifested signs of this pathology in the oral cavity is suggested, since the epithelial cells of the oral mucosa have ACE2 receptors.

We highlight the importance of longitudinal studies aimed at oral implications due to the new coronavirus, which can elucidate the mechanisms underlying the development of possible oral lesions since there is no consensus on whether the reported ulcers, petechiae, and vesiculobullous lesions represent intraoral manifestations of SARS-CoV-2 infection.
GOMES, A. C.; FERREIRA, D. S.; SILVA, M. M.; BARROS, C. C. S.; MENEZES, N. S. \& SANTOS, H. B. P. Alteraciones orales en un paciente con COVID-19: reporte de un caso y actualización de los principales hallazgos. Int. J. Odontostomat., 15(2):315-319,2021.

RESUMEN: EI COVID-19 se caracterizó como una pandemia debido a la diseminación mundial y la gravedad con la que la enfermedad ataca al organismo humano. Se han observado algunas lesiones orales en pacientes con COVID-19. Sin embargo, todavía no hay evidencia concreta de la influencia del SARS-CoV-2 en el cuerpo humano, especialmente en la cavidad oral. En este contexto, el presente reporte analiza un caso de un paciente con COVID-19 con alteraciones orales. El paciente de sexo masculino presentó lesiones ulcerativas de sintomatología dolorosa y petequias en la mucosa oral. Este estudio también realizó una revisión de la literatura de las principales alteraciones orales reportadas en la literatura. Si bien se deben realizar más estudios con un mayor número de pacientes, el presente reporte de caso puede haber manifestado signos de esta patología en la cavidad oral ya que las células epiteliales de la mucosa oral tienen receptores ACE2.

PALABRAS CLAVE: coronavirus, manifestaciones bucales, salud oral.

\section{REFERENCES}

Abu-Hammad, S.; Dar-Odeh, N. \& Abu-Hammad, O. SARS-CoV-2 and oral ulcers: A causative agent or a predisposing factor? Oral Dis., 2020. DOI: https://www.doi.org/10.1111/odi.13498

Al-Khatib, A. Oral manifestations in COVID-19 patients. Oral Dis., 27 Suppl. 3:779-80, 2020.

Amorim Dos Santos, J.; Normando, A. G. C.; Carvalho da Silva, R. L.; De Paula, R. M.; Cembranel, A. C.; Santos-Silva, A. R. \& Silva Guerra, E. N. Oral mucosal lesions in a COVID-19 patient: New signs or secondary manifestations? Int. J. Infect. Dis., 97:326-8, 2020.

Carreras-Presas, C. M.; Amaro Sánchez, J.; López-Sánchez, A. F.; Jané-Salas, E. \& Somacarrera Pérez, M. L. Oral vesiculobullous lesions associated with SARS-CoV-2 infection. Oral Dis., 27 Suppl. 3:710-2, 2020.

Ciccarese, G.; Drago, F.; Boatti, M.; Porro, A.; Muzic, S. I. \& Parodi, A. Oral erosions and petechiae during SARS-CoV-2 infection. J. Med. Virol., 93(1):129-32, 2020.

Giannis, D.; Ziogas, I. A. \& Gianni, P. Coagulation disorders in coronavirus infected patients: COVID-19, SARS-CoV-1, MERSCoV and lessons from the past. J. Clin. Virol., 127:104362, 2020.

Guan, W.; Ni, Z.; Hu, Y.; Liang, W.; Ou, C.; He, J.; Liu, L.; Shan, H.; Lei, C.; Hui, D. S. C.; et al. Clinical characteristics of Coronavirus Disease 2019 in China. N. Engl. J. Med., 382:1708-20, 2020.

Hamed, M. A. An overview on COVID-19: reality and expectation. Bull. Natl. Res. Cent., 44(1):86, 2020.

Jimenez-Cauhe, J.; Ortega-Quijano, D.; Carretero-Barrio, I.; SuarezValle, A.; Saceda-Corralo, D.; Moreno-Garcia del Real, C. \& Fernandez-Nieto, D. Erythema multiforme-like eruption in patients with COVID-19 infection: clinical and histological findings. Clin. Exp. Dermatol., 45(7):892-5, 2020. 
Kahraman, F. C. \& Ças kurlu, H. Mucosal involvement in a COVID19-positive patient: A case report. Dermatol. Ther., 33(4):e13797, 2020.

Lechien, J. R.; Chiesa-Estomba, C. M.; De Siati, D. R.; Horoi, M.; Le Bon, S. D.; Rodriguez, A.; Dequanter, D.; Blecic, S.; El Afia, F.; Distinguin, L.; et al. Olfactory and gustatory dysfunctions as a clinical presentation of mild-to-moderate forms of the coronavirus disease (COVID-19): a multicenter European study. Eur. Arch. Otorhinolaryngol., 277(8):2251-61, 2020.

Petrescu, N.; Lucaciu, O. \& Roman, A. Oral mucosa lesions in COVID-19. Oral Dis., 2020. DOI: https://www.doi.org/10.1111/ odi.13499.

Ponce, J. B. \& Tjioe, K. C. Overlapping findings or oral manifestations in new SARS-CoV-2 infection. Oral Dis., 27 Suppl. 3:781-2, 2020.

Rocha, B. A.; Souto, G. R.; Grossmann, S. M. C.; de Aguiar, M. C. F.; de Andrade, B. A. B.; Romañach, M. J. \& Rebello Horta, M. C. Viral enanthema in oral mucosa: A possible diagnostic challenge in the COVID-19 pandemic. Oral Dis., 27 Suppl. d3:776-8, 2020.

Soares, C. D.; de Carvalho, R. A.; de Carvalho, K. A.; de Carvalho, M. G. F. \& de Almeida, O. P. Letter to Editor: Oral lesions in a patient with Covid-19. Med. Oral Patol. Oral Cir. Bucal, 25(4): e563-4, 2020.

Weiss, S. R. \& Navas-Martin, S. Coronavirus pathogenesis and the emerging pathogen severe acute respiratory syndrome coronavirus. Microbiol. Mol. Biol. Rev., 69(4):635-64, 2005.

Xu, H.; Zhong, L.; Deng, J.; Peng, J.; Dan, H.; Zeng, X.; Li, T. \& Chen, Q. High expression of ACE2 receptor of 2019-nCoV on the epithelial cells of oral mucosa. Int. J. Oral Sci., 12:8, 2020. DOI: https://www.doi.org/10.1038/s41368-020-0074-x.

Zhou, P.; Yang, X. L.; Wang, X. G.; Hu, B.; Zhang, L.; Zhang, W.; Si, H. R.; Zhu, Y.; Li, B.; Huang, C. L.; et al. A pneumonia outbreak associated with a new coronavirus of probable bat origin. Nature, 579:270-3, 2020.

Zou, X.; Chen, K.; Zou, J.; Han, P.; Hao, J. \& Han, Z. Single-cell RNA-seq data analysis on the receptor ACE2 expression reveals the potential risk of different human organs vulnerable to 2019nCoV infection. Front. Med., 14(2):185-192, 2020.
Corresponding author:

Hellen Bandeira de Pontes Santos Av. Frei Galvão, 12 - Gramame

João Pessoa - PB

58067-698

BRAZIL

E-mail: hellenbps@hotmail.com 